\title{
Strategic Behavior and Earnings Management: Evidence from Europe
}

\author{
Luciano Pinheiro de Sá ${ }^{1}$ (i) \\ Lúcia Lima Rodrigues ${ }^{2}$ \\ Josir Simeone Gomes ${ }^{3}$
}

\section{Abstract}

Purpose - This study analyzes the relationship between strategic behavior and earnings management in a sample of Eurozone companies between 2009 and 2018.

Theoretical framework - The theoretical lens used is the agency theory derived from the managers-owners problem. As support for understanding strategic behavior, we adopted Miles et al. (1978). For earnings information quality, we follow Dechow, Ge, and Schrand (2010).

Design/methodology/approach - We opted for a positivist approach and tested our hypotheses on panel data, using regression models and the average test. From Miles et al. (1978), we used the measurement adopted by Bentley, Omer, and Sharp (2013) on public data from Eurozone companies to categorize them in the three typologies of strategic behavior. To estimate earnings management, we adopted the performance-modified Jones model.

Findings - There is the suggestion that, in the case of Eurozone companies, business strategy is positively related to earnings management. It was not possible to find statistically significant results of prospectors managing their earnings differently from other companies. We tested the relationships for positive and negative abnormal accruals. We cannot affirm that there is any relationship with the strategy of managing positive earnings. In the case of negative errors, the study suggests that prospectors act to reduce their earnings.

Practical \& social implications of research - This study contributes to the literature on earnings information quality, especially regarding earnings management. The study both corroborates and departs from the previous literature. It shows the relationship between strategy and earnings management, however, we cannot confirm that prospectors engage in higher levels of earnings management. As practical implications, the evidence that emerged could serve as a contribution to other researchers, regulators, and players in the European financial market.

1. Federal University of Juiz de Fora (UFJF), Finance and Controllership, Juiz de Fora-Brazil.

2. University of Minho, Department of Management, Braga, Portugal.

3. University of Grande Rio, Strategy and Governance, Rio de Janeiro, Brazil.

How to cite:

Pinheiro de Sá, L., Rodrigues, L. L., \& Gomes, J. S. (2021). Strategic Behavior and Earnings Management: Evidence from Europe. Revista Brasileira de Gestão de Negócios, 23(4), p.714-727.
Received on:

11/25/2019

Approved on:

03/12/2021

Responsible Editor:

Prof. Dr. Ivam Ricardo Peleias

\section{Evaluation process:}

Double Blind Review

\section{Reviewers:}

Cristian Baú Dal Magro; One of the reviewers decided not to disclose his/ her identify

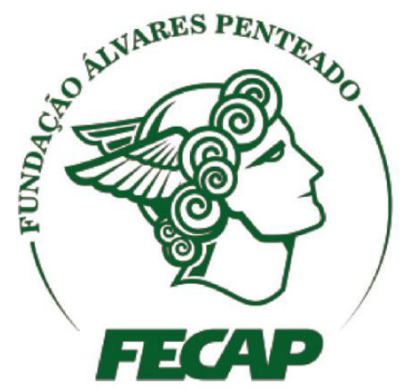

Revista Brasileira de Gestáo de Negócios

https://doi.org/10.7819/rbgn.v23i4.4129 
Originality/value - The originality of the research derives from the application of agency theory, earnings quality studies, and business strategy to the European market.

Keywords - agency theory; earnings management; strategy behavior.

\section{Introduction}

From a longitudinal viewpoint, academics offer different types of works that describe how companies compete in their markets. Miles, Snow, Meyer, and Coleman (1978) describe three reasonably distinct types of competition for companies in their markets. The so-called prospector and defender companies are at the extremes, presenting different behaviors. In the intermediate profile, there are analyzer companies with a moderate degree of mechanization and routine that allow, for example, flexibility for new business activities, constant growth with market penetration, and a focus on product and market development (Higgins, Omer, \& Phillips, 2015). Prospectors seek new and innovative products and operate based on a diversified decision-making matrix. Defenders act vertically in an integrated manner, presenting a very narrow product line and a relevant focus on cost reductions (Bentley, Omer, \& Sharp, 2013).

In a connected market environment, where suppliers, fund providers, workers, and customers are global, companies set standards for strategic choices. Reference works have sought, in some way, to categorize these patterns. These choices characterize most organizations, allowing researchers, through public information, to fit them into standard typologies, which mitigate some research problems that need this framework (Miles, Snow, Meyer, \& Coleman Jr, 2003).

Better earnings quality information enables users a better basis for their decisions. A strong capital market assumes that companies' information has acceptable confidence levels. The information needs to represent the results of decisions that are made and should not be influenced by discretionary decisions (Dechow, Ge, \& Schrand, 2010).

In light of these conditions, studies related to earnings quality are important. The present research is based on the work of Dechow et al. (2010) that developed proxies for earnings quality. It places the abnormal accruals (accruals quality) proxy within the domain of earnings quality. We start based on the hypothesis of earnings management research that managers conduct their actions believing that users of financial reports can be misled. Studies that take this view for granted are interesting not only for academics, but also for professionals and regulators (Kothari, Leone, \& Wasley, 2005).

As a consequence of the earnings quality phenomenon, situations such as a greater propensity for litigation, audit opinions, market assessments, executive remuneration, cost of equity, and third parties' and analysts' forecasts are usually analyzed. In view of this broad spectrum, studies involving earnings quality are important for auditors, capital market participants, boards of directors, compensation committees, and analysts in general (Dechow et al., 2010).

In the late 1970s, while developing the theory of strategic behavior, Miles et al. (1978) dealt with the possibility that the typologies of strategy relate to accounting choices. As additional examples of the concern about the relationship between strategic decisions and accounting choices, Bentley, Omer, and Sharp (2013) showed that organizations' strategic decisions influence size, level of complexity, and processes and can contribute to decisions about the accounting choices of managers, including the possibility of discretionary decisions, which reduce the quality of accounting information.

There is robust research on measuring accounting information quality, especially regarding earnings management, including that of Cameran, Campa, and Pettinicchio (2014), Marques, Rodrigues, and Craig (2011), and Mendes and Rodrigues (2007). However, there are gaps in terms of connecting business strategy and earnings quality in the European market, which suggests a space to be filled.

Considering the consequences of earnings quality and the latent gap in terms of works that address strategy and accounting information quality in European companies, this article aims to fill that void. The main objective is to investigate the relationship between strategic behavior and earnings management. We opted for a sample of companies operating in the Eurozone, a market with low inflation and interest rates and better availability of business data.

The companies studied are listed in the Eurozone. The data on them were captured from the Amadeus database 
and cover 2011 to 2018. We used this period because by 2011 the companies had already been implementing the International Financial Reporting Standards for some years, as well as because of the database restrictions. The abnormal accruals were obtained using the performance-modified Jones model. Absolute, positive, and negative errors were treated as dependent variables in multiple panel data regression models using fixed and variable effects and ordinary least squares (OLS). We concluded that strategy is related to earnings management. We were not successful in confirming that prospector companies manage their earnings differently compared to other types.

This research is positivist since it uses data and statistical tools. It is divided into six sections, including this introduction. The literature review, theoretical foundations, and hypotheses are presented in section 2. The methodology is addressed in the third section. The results are analyzed in the fourth section. Finally, in section 5 , the conclusions are presented.

\section{Literature review}

\section{I Theoretical foundations}

This research aims to investigate the relationship between strategic behavior and earnings management in companies in the Eurozone. This section presents the theoretical foundations, as a starting point for the development of the research.

The management literature presents several types of business strategies, which describe how companies compete in their respective market environments. For Higgins et al. (2015), who observed the works of Miles et al. (1978 and 2003), Porter (1980), March (1991), and Treacy and Wiersema (1995), a common characteristic among the typologies lies in the categorization of two extremes of organizational types. In the case proposed by Miles et al. (1978), the differentiations are based on the analyzer and prospector behavioral patterns. In this research, we adopted the fundamentals of the theory disseminated by Miles et al. (1978) regarding the standards of strategic behavior that companies adopt. For these authors, organizations define their product market domains and build mechanisms with their structures and processes to pursue the strategy.

The work of Miles et al. (1978) has been used as theoretical support in the continuous evolution of research that deals with business strategy. Researchers such as Higgins et al. (2015), Bentley et al. (2013), and Ittner and Larcker (2012) mention the better operationalization of the data that are made available by companies, in which it is possible to identify the standard strategic behavior.

As a definition, prospector companies are those that continually look for new and innovative products and operate based on a diversified decision matrix. At the other end of what is proposed in the theory, defenders are typically vertically integrated, have a restricted set of specialized decisions in a very narrow product line, and are strongly focused on cost reductions (Bentley et al., 2013).

In the intermediate profile, we can find analyzers, which have a moderate degree of mechanization and routine that allow, for example, flexibility for new business activities, constant growth with market penetration, and a focus on the development of products and markets (Higgins et al., 2015). More complete characteristics of the typologies are shown in Table 1.

Miles et al. (1978) argue that strategy typologies are related to accounting choices. Some studies are supported by this relationship, especially regarding earnings management. The concern can be seen in the research by Wu, Gao, and Gu (2015) that sought to understand how business strategy and competition in the market are related to earnings management practices through operational decisions. Bentley, Omer, and Sharp (2013) investigated the connections between business strategy and irregularities in the disclosure of accounting information and audit efforts. Finally, Houqe, Kerr, and Monem (2013) analyzed the relationship between strategy and earnings management in companies in the United States.

Improving the quality of accounting information offers users better conditions for their decision-making. As earnings management is one of the approaches to studying earnings quality, it is important to investigate it and understand its relationship with aspects of the business (Dechow, Ge, \& Schrand, 2010).

Martinez (2008) finds in the works of Schipper (1989) and Healy and Wahlen (1999) the most common definitions of earnings management, namely:

\section{[...] a purposeful intervention in the external financial reporting process, with the intent of obtaining some private gain [...] earnings management occurs when managers use judgment in financial reporting to either mislead some stakeholders about the underlying economic performance of the company, or to influence contractual outcomes that depend on reported accounting numbers (Martinez, 2008, p. 8).}


Table 1

Characteristics of prospector and defender companies, according to strategic types

\begin{tabular}{|c|c|c|}
\hline & Prospectors & Defenders \\
\hline Definition & $\begin{array}{l}\text { They continuously seek new and innovative } \\
\text { products and operate based on a diversified } \\
\text { decision matrix. }\end{array}$ & $\begin{array}{l}\text { Vertically integrated. Restricted set of specialized } \\
\text { decisions. Narrow product line and cost reductions. }\end{array}$ \\
\hline Competitive advantage & Market innovation. & Efficiency and stability \\
\hline Competitive disadvantage & $\begin{array}{l}\text { Risk of low profitability and high exposure of } \\
\text { resources. }\end{array}$ & $\begin{array}{l}\text { Adaptability to market changes and threat of } \\
\text { obsolescence. }\end{array}$ \\
\hline Research and development & Intense research and development. & Minimum research and development. \\
\hline Efficiency & $\begin{array}{l}\text { They never reach maximum efficiency in } \\
\text { production and distribution systems. }\end{array}$ & $\begin{array}{l}\text { They achieve efficiency in distribution and } \\
\text { production systems. }\end{array}$ \\
\hline Growth & $\begin{array}{l}\text { Growth occurs in stages through the development } \\
\text { of new products. }\end{array}$ & $\begin{array}{l}\text { Cautious and incremental growth through market } \\
\text { penetration. }\end{array}$ \\
\hline Marketing & A strong focus on the marketing function. & A weak focus on the marketing function. \\
\hline $\begin{array}{l}\text { Organization, structure, and } \\
\text { stability }\end{array}$ & Decentralized control. & Centralized control. \\
\hline Capital intensity & Low degree of mechanization. & High degree of mechanization. \\
\hline
\end{tabular}
Source: Adapted from “Business Strategy, Financial Reporting Irregularities, and Audit Effort,” by K.A. Bentley, T. C. Omer, \& N. Y. Sharp, 2013, Contemporary Accounting Research, 30.

Another important theoretical basis for this study that involves earnings management is agency theory. According to Dal Magro, Lavarda, and Klann (2019), almost $61 \%$ of the papers seek theoretical support in this theory. Agency problems between managers and owners emerge from the separation of ownership and control (Jensen \& Meckling, 1976).

Dechow et al. (2010) develop a broad review of the determinants of proxies and the consequences of phenomena that impact earnings quality. The authors start from the premise that "Higher quality earnings provide more information about the features of a firm's financial performance that are relevant to a specific decision made by a specific decision-maker" (Dechow et al., 2010, p. 344). For studies on earnings quality, they advocate five proxies, in which earnings management is one of the measures.

Abnormal accruals are used as a reference for earnings management, as illustrated by Dal Magro et al. (2019), DeFond and Park (2001), and Martinez and Reis (2010), for example.

\subsection{Literature review and hypotheses}

Based on the theory of strategic behavior by Miles et al. (1978), in which strategic decisions affect accounting choices, in this study it is argued that corporate strategy is related to accounting choices. Thus, we assume that discretionary decisions can modify accounting earnings, insofar as strategic investment decisions and accounting choices are taken together (Houqe, Kerr, \& Monem, 2013).

Different organizational strategic behaviors are associated with different levels of discretion. Organizations that operate in innovative markets and with a differentiation strategy conduct the management actions required in these types of competitive markets using more aggressive accounting practices. Defenders tend to lower their levels of earnings management when compared to those adopted by analyzers or prospectors (Dal Magro, Jesus Silva, \& Klann, 2013).

Higgins et al. (2015) examined the relationship between business strategy and aggressiveness in tax payments. They chose to adopt the precepts of strategic behavior patterns based on the theory of Miles et al. (1978). They identified that prospector companies avoid more taxes than defenders. According to the researchers, there is evidence that prospectors make more aggressive tax decisions. Prospectors take greater risks and deal with additional degrees of uncertainty.

Other evidence of the relationship between different business strategies and earnings quality appears in the research by Bentley et al. (2013). They investigated the relationship between business strategy and audit effort, similarly using the foundations of Miles et al. (1978) that are also found in the works of Dal Magro et al. (2017) and Higgins et al. (2015). Bentley et al. (2013) found evidence that audit firms 
can incorporate business strategy in the development of their audit planning, with greater impacts on the extent of the audit work in prospector companies in relation to defenders.

From the empirical evidence, Hypothesis 1 emerged, that corporate strategy is related to earnings management in European companies. This hypothesis is supported by the results of Dal Magro, Jesus Silva, and Klann (2017), Higgins et al. (2015), Bentley et al. (2013), Wu, Gao, and Gu (2015), and Houqe, Kerr, and Monem (2013).

As a second hypothesis, we investigate whether European companies with prospector typologies engage in higher levels of earnings management. Some studies are divergent as to whether a specific type has a higher or lower level of earnings management activity. For example, Dal Magro, Jesus Silva, and Klann (2017), Higgins et al. (2015), and Bentley et al. (2013) understand that prospectors act in a more significant way, whether in earnings management or in fiscal aggressiveness. However, Wu, Gao, and Gu (2015) and Houqe, Kerr, and Monem (2013), in the latter case only for periods considered to have low variability in economic growth, understand that there is no evidence that prospectors manage earnings the most. We chose to test the prospector organizations for the highest or lowest level of earnings management.

\section{Methodological Procedures}

\section{I Sample and data source}

The sample consists of companies listed in the Eurozone. We chose European companies because we observed that previous studies refer to other markets (Ball \& Shivakumar, 2005; Bentley, Omer, \& Sharp, 2013; Healy \& Wahlen, 1999; Higgins, Omer, \& Phillips, 2015; Hogan, 2013; Houqe, Kerr, \& Monem, 2013; Wu, Gao, $\& \mathrm{Gu}, 2015)$. We analyzed a period of 10 years, from 2009 to 2018 , because by this time the international accounting standards were already consolidated and also because of database restrictions.

The standard deviation of three years for the number of employees, one of the dimensions for calculating the strategy measure, conditioned the final analysis period to be from 2011. For the calculation of employee turnover in 2011, we needed data from 2009, 2010, and 2011, for example. Thus, the final database includes information from 2011 to 2018, as we cannot calculate this measure for 2010 or 2009 since we would need data from 2008 and 2007, respectively, which were not captured in the database.

We opted to exclude cases in which the data did not allow the calculation of the measures, whether for strategy or earnings management. The data were obtained from the Amadeus database. The initial sample was composed of 428 companies. Initially, all sectors of activity were included in the sample, except companies with financial operations or similar.

We adopted panel data with repeat observations of the same companies over a period. Although we mention the results from the OLS, we apply the Hausman test to determine which model between fixed or random effects is most appropriate.

\subsection{Variables and models}

\subsection{Strategic behavior}

Strategy, which is based on the work of Ittner and Larcker (2012) and Miles et al. (1978), is evaluated using six different measures (Bentley et al., 2013). In a year, for each dimension, the company receives a concept that varies from one to five, giving a total sum of all dimensions between six and 30. Companies that present totals closer to the minimum are more adherent to defender characteristics. On the other hand, those with totals closer to the maximum value have aspects of prospectors. The six dimensions, with the respective calculation methodologies, are shown in Table 2.

The companies were categorized using the threedigit SIC codes as a reference, as shown in Table 3.

In its sector of activity, each company receives a score of 5 for the highest quintile, 4 for the second highest quintile, and so on, down to the lowest quintile, with a score of 1 . The sixth dimension, capital intensity (D6), receives an inverted treatment as to the distribution of the score. In the case of D5, employee turnover, the calculation of the standard deviation is based on three years (Bentley et al., 2013; Higgins et al., 2015).

After the distribution of the concepts of all dimensions to the companies, by year and sector of activity, we added up a discrete measure with a minimum value of six and a maximum of 30 points, for each company. Bentley et al. (2013) suggest three categories. The first group contains defender companies with totals greater than or equal to six and less than 12 . The second group contains analyzers 
Table 2

\section{Strategic behavior: dimensions, calculation formulas, and theoretical justifications}

\begin{tabular}{|c|c|c|}
\hline Dimension & $\begin{array}{c}\text { Calculation } \\
\text { formula }\end{array}$ & Theoretical justification \\
\hline $\begin{array}{l}\mathrm{D} 1_{\mathrm{i}, \mathrm{t}-} \text { Research and } \\
\text { Development to Sales Ratio. } \\
\mu \mathrm{RDS}\end{array}$ & $\frac{r_{\mathbf{i}, t}}{s_{i, t}}$ & $\begin{array}{l}\text { The greater the proportion of research and development in relation to sales, the } \\
\text { greater the propensity of the company to develop and search for new products. }\end{array}$ \\
\hline $\begin{array}{l}\mathrm{D} 2_{\mathrm{i}, \mathrm{t}-} \text { Proportion of employees } \\
\text { over sales. } \mu \text { EMPS }\end{array}$ & $\frac{\mathrm{emp}_{\mathbf{i}, \mathbf{t}}}{\mathbf{s}_{\mathbf{i}, \mathbf{t}}}$ & $\begin{array}{l}\text { This indicates the company's ability to produce and distribute its products efficiently, } \\
\text { which is more in line with the defender typology. }\end{array}$ \\
\hline $\begin{array}{l}\mathrm{D} 3_{\mathrm{i}, \mathrm{t}-} \text { Variation in total } \\
\text { revenue. } \mu \Delta \mathrm{V}\end{array}$ & $\frac{\mathbf{s}_{\mathbf{i}, \mathbf{t}}}{\mathbf{s}_{\mathbf{i}, \mathbf{t}-1}}-1$ & $\begin{array}{l}\text { This supports the company's historical growth as an indicator of greater growth } \\
\text { opportunities, in line with prospectors. }\end{array}$ \\
\hline $\begin{array}{l}\text { D4 } 4_{\mathrm{i}, \mathrm{t}-\mathrm{-}} \text { Marketing over sales. } \\
\mu \mathrm{MT}\end{array}$ & $\frac{\mathbf{m k t}_{\mathbf{i}, \mathbf{t}}}{\mathbf{s}_{\mathbf{i}, \mathbf{t}}}$ & $\begin{array}{l}\text { This places a greater emphasis on market share and sales. A greater relationship } \\
\text { suggests theoretical alignment with prospectors. }\end{array}$ \\
\hline $\begin{array}{l}\text { D5 } 5_{i, t-\text { Employee turnover. }} \\
\mu \text { EMPTURN }\end{array}$ & SDemp $_{\mathbf{i}, \mathbf{t}}$ & $\begin{array}{l}\text { The theoretical support is that defender companies have more stability for employees. } \\
\text { Larger standard deviations in the number of employees suggest greater turnover. }\end{array}$ \\
\hline $\mathrm{D}_{\mathrm{i}, \mathrm{t}-}$ Capital intensity. $\mu \mathrm{CAP}$ & $\frac{\text { netass }_{\mathbf{i}, \mathbf{t}}}{\text { ass }_{\mathbf{i}, \mathbf{t}}}$ & It is argued that defender companies have a higher intensity of fixed capital. \\
\hline
\end{tabular}

Note. The table shows the dimensions of strategic behavior, calculation methodology, and theoretical justification. Source: Bentley et al. (2013); Higgins et al. (2015); Ittner and Larcker (2012); Miles et al. (1978). Where: rd: spending on research and development of company $i$ in year $t$; $s$ : the annual sales of company $i$ in year $t$; mkt: sales, general, and administrative expenses obtained through gross profit minus operating income and depreciation; emp: personnel spending of company i in year t; netass: the net assets of company i in year $t$; and ass: the total assets of company $i$ in year $t$.

Table 3

Sectors of activity: sector coding, SIC code, and description

\begin{tabular}{ccc}
\hline Sector & SIC code & Description \\
\hline 1 & $010-099$ & Agriculture, Forestry, and Fisheries \\
2 & $100-149$ & Mining and Construction \\
3 & $200-399$ & Manufacturing \\
4 & $400-499$ & Transport, Communications, Electricity Services, Gas, and Sanitation \\
5 & $500-599$ & Wholesale / Retail Trade \\
6 & $700-899$ & Services \\
\hline
\end{tabular}

with totals greater than or equal to 12 points and less than 24 points. And the third group is made up of prospector companies with totals greater than or equal to 24 points, up to a maximum of 30 points. We adjusted this score, for this work, as the STRATi,t measure.

\subsubsection{Accruals quality}

The empirical measure for earnings management is accruals quality. It originates from the performance-adjusted Jones model presented by Kothari et al. (2005) and used by Martinez and Moraes (2017) to estimate abnormal discretionary accruals. According to Dal Magro et al.
(2019), approximately two out of five surveys make use of this model. Discretionary accruals abnormalities have been adopted as an approximation of earnings management in the works of Ferreira et al. (2012), Marques, Rodrigues, and Craig (2011), Martinez and Reis (2010), Orestes da Silva and Bezerra (2010), Santos, Machado, and Scarpin (2012), and SeJati (2009).

The performance-adjusted model seeks to control the calculation of discretionary accruals in cases where companies are grouped into a single group, as in the case of this research. The model has the following formulation: 
$\operatorname{ACC}_{i, t}=\beta_{0}+\beta_{1}\left(\frac{1}{\text { ATIVOS }_{i, t-1}}\right)+\beta_{2}\left(\operatorname{VARV}_{i, t}-\operatorname{VARR}_{i, t}\right)+\beta_{3} N C A_{i, t}+\beta_{3} \operatorname{ROA}_{i, t-1}++$ ERRO $_{i, t}$

Model 1

Note. $\beta_{0}$ is the intercept and ERROR is an error term considered as an approximation of earnings management. Other elements of Model 1 are defined in Table 4.

After composing the strategy measure (see Tables 2 and 3), and devising the approach to earnings management (see Model 1), Models 2 and 3 measure whether there is a relationship between strategic behavior and earnings management in Eurozone companies.

$$
\boldsymbol{E R R O}_{i, \boldsymbol{t}}=\beta_{0}+\beta_{1} \boldsymbol{S T R A T}_{\boldsymbol{i}, \boldsymbol{t}}+\beta_{3} \boldsymbol{X}_{\boldsymbol{i}, \boldsymbol{t}}+\gamma_{\boldsymbol{i}}+\varepsilon_{\boldsymbol{i}, \boldsymbol{t}}
$$

Model 2

Note. ERRORi,t is the absolute value of the stochastic error in Model $1 ; \beta_{0}$ is the intercept; STRATi,t is the discrete variable obtained through positioning in quintiles based on six measures of strategic behavior pattern. It ranges between six and 30 points; $\mathrm{Xi}, \mathrm{t}$ is a vector of controls. $\gamma \mathrm{i}$ are dummies for each firm and $\varepsilon$ is the model's stochastic error.

To answer whether prospector companies engage in higher levels of earnings management (Hypothesis 2), we developed Model 3.

$$
\boldsymbol{E R R O}_{\boldsymbol{i}, \boldsymbol{t}}=\alpha_{0}+\alpha_{1} \boldsymbol{P R O S P E C}_{\boldsymbol{i}, \boldsymbol{t}}+\alpha_{3} \boldsymbol{X}_{\boldsymbol{i}, \boldsymbol{t}}+\gamma_{\boldsymbol{i}}+\varepsilon_{\boldsymbol{i}, \boldsymbol{t}} \quad \text { Model } 3
$$

Note. PROSPECi,t assumes 1 , if company $\mathrm{i}$ in period $\mathrm{t}$ presents STRAT greater than or equal to 24 points. Other variables of the model were already described previously.

Models with the same specifications, but with the independent variables ERROR2i,t and ERROR3i,t, will be estimated. ERROR2i,t is the positive value of the stochastic error in Model 1, a proxy for positive earnings management. ERROR3i,t is the negative value of the stochastic error in Model 1, a proxy for negative earnings management. Positive or negative $\mathbf{E R R O R}_{\mathrm{it}}$ values indicate whether the company engages in management to increase its earnings (positive sign) or to decrease its earnings (negative sign) (Martinez, 2008).

As control variables, according to SeJati (2009), we also included SIZE, as the size of the company computed as the natural logarithm of the total assets of company $i$ in year $t$; and LEV, as the financial leverage of company $i$ in year $t$, computed as total liabilities divided by total assets. The results that support the hypotheses are observed from the coefficients $\beta_{1}$ and $\alpha_{1}$ of Models 2 and 3.

\section{Presentation and Analysis of Results}

\section{I Descriptive results}

The results and analyses of this work are described in this section. We also discuss the results using previous literature. Abnormal accruals, obtained by the performancemodified Jones model, had an adjustment quality of $9.7 \%$, where the main measures of the model had significance levels of $1 \%$. Only changes in sales and receivables are not significantly related to accruals. The control variables SECTOR1, SECTOR3, SECTOR4, and SECTOR6 have statistical significance levels of $10 \%, 5 \%, 1 \%$, and $5 \%$, respectively. The year control variables are not significant at levels below $10 \%$. Covering the period from 2011 to 2018, we obtained information on the strategy composition of 428 companies in a total of 2,484 observations. As for the management proxy results, the database provides 1,890 observations. There is a significant majority are analyzers, accounting for $89.49 \%$ of the observations. Next, defenders emerge, accounting for $6.80 \%$ of the observations. Finally, 3.70\% are prospectors.

Table 4

\begin{tabular}{|c|c|c|}
\hline Variable & Description & Data source \\
\hline ACC & $\begin{array}{l}\text { Total accruals computed as profits before extraordinary items minus operating cash flow divided by } \\
\text { total assets. }\end{array}$ & Amadeus \\
\hline ASSETS & Total assets & Amadeus \\
\hline VARS & Variation in sales between the current year and the previous year, divided by total assets. & Amadeus \\
\hline VARR & Change in receivables between the current year and the previous year, divided by total assets. & Amadeus \\
\hline NCA & Non-current assets in the current year divided by the total assets of the previous year. & Amadeus \\
\hline ROA & Return on assets, computed as earnings before extraordinary items divided by total assets. & Amadeus \\
\hline
\end{tabular}

Regression model: variables, description, and data source of Model 1

Source: Adapted from "Relationship between auditors' fees and earnings management," by A. L. Martinez \& A. de J. Moraes, 2017,

Revista de Administração de Empresas, 57. 
As for the sector in which the companies operate, $41.12 \%$ of the observations are in the manufacturing sector, with $37.85 \%$ in services. We could not find prospectors in three sectors: agriculture, forestry, and fisheries (SIC code 010-099), mining and construction (SIC code 100149), and transport, communications, electricity services, gas, and sanitation (SIC Code 400-499). For the entire set of observations, the average of the STRAT construct was 17.05 with a standard deviation of 3.68. Segregating by type of strategy, prospector, defender, and analyzer companies have an average of 25.01, 9.98, and 17.36, respectively.

The final results show a total of five Eurozone countries, with France and Germany representing 75.28\% and $23.43 \%$ of the observations, respectively. Austria $(0.20 \%)$, Ireland $(0.56 \%)$, and Luxembourg $(0.52 \%)$ also appear in the final set.

\subsection{Results for hypothesis I}

The theoretical assumption for the development of the hypotheses originate from the theory of strategic behavior by Miles et al. (1978), in which strategic typologies can be related to accounting choices. Research has shown the relationship between strategy and accounting information, as explained by Bentley et al. (2013), Wu, Gao, and Gu (2015), Dal Magro et al. (2017), and other previously-discussed authors.

As a first hypothesis, we assumed that corporate strategy is related to earnings management in European companies. A segregated analysis of the averages, based on the application of averaging tests, already provides some evidence. With all observations, the average of the earnings management measure variable is 0.038 . Separating only the observations of the analyzer companies, the average is 0.037 , at $1 \%$ significance, which suggests a lower level of earnings management for a specific typology. The earnings management situation is similar when we analyze the average of the defenders, which is close to the global average.

When the prospectors are separated, the average error increases to 0.058 , with a significance of $1 \%$. Based on the global average, prospectors have a $53 \%$ higher average, which shows a higher level of earnings management for companies with strategic behavior patterns closer to those of prospectors.

The means for positive (ERROR2) and negative (ERROR3) earnings management also show similar behavior. The highlight is the negative anomalies in accruals. In this case, both analyzer and prospector companies have significantly different averages from the global average. In the case of the prospectors, the average is $73 \%$ higher than the global average, which may suggest intense earnings management in the prospectors to reduce accounting earnings. The panel data and the literature on the topic suggest that individual characteristics should be controlled. We applied the Hausman test (Verbeek, 2017, p. 394) in the two guiding models and the results indicated that fixed effects should be controlled.

Table 5 consolidates the results of the regression models for the investigation of the relationship between strategy and earnings management (Model 2); and whether the prospector companies engage in more earnings management than the other companies (Model 3). We present the results of OLS, fixed, and random effects regressions for comparisons.

For hypothesis 1, the results of Model 2, with fixed effects, suggest that the patterns of strategic behavior are related to the earnings management proxy. The $\beta_{1}$ coefficient associated with the STRAT variable is equal to 0.00138 , with $90 \%$ statistical confidence. This information shows that for each unit of evolution in the STRAT strategy measure, the abnormality of accruals increases, on average, 0.00138 , which allows it to be suggested that there is a positive association between corporate strategy and earnings management.

Also in the analysis of Model 2 with fixed effects, the constant appears with a significance of $1 \%$ and its result was 0.183 . The size of the company is negatively related to earnings management, with a confidence level greater than $99 \%$, which suggests that companies with fewer assets engage in more intensive earnings management practices. This result is similar to that found by SeJati (2009), in studies of Malaysian companies.

The LEV financial leverage observations in the year 2012 and the SECTOR6 services sector do not suggest significant relationships with earnings management.

\subsection{Results for hypothesis 2}

The average for earnings management for prospector companies is the highest among the three types, with $1 \%$ statistical significance, which suggests that these companies engage in higher levels of earnings management. However, Model 3, Table 1, Column (4), which supports the investigation of whether companies 
Table 5

Results of regression models: earnings management. Absolute error values, Eurozone companies - 2011 to 2018.

\begin{tabular}{|c|c|c|c|c|c|c|}
\hline \multirow{2}{*}{ Variables } & (1) & (2) & (3) & (4) & (5) & (6) \\
\hline & OLS - Model 2 & OLS - Model 3 & FE - Model 2 & FE - Model 3 & RE - Model 2 & RE - Model 3 \\
\hline \multirow[t]{2}{*}{ STRAT } & 0.000577 & & $0.00138^{*}$ & & $0.000929^{*}$ & \\
\hline & $(0.000353)$ & & $(0.000794)$ & & $(0.000500)$ & \\
\hline \multirow[t]{2}{*}{ SIZE } & $-0.00350^{* * *}$ & $-0.00333^{* * *}$ & $-0.0146^{* * *}$ & $-0.0142^{* * *}$ & $-0.00417^{* * *}$ & $-0.00399^{* * *}$ \\
\hline & $(0.000498)$ & $(0.000475)$ & $(0.00452)$ & $(0.00441)$ & $(0.000860)$ & $(0.000847)$ \\
\hline \multirow[t]{2}{*}{ LEV } & $0.0169^{* * *}$ & $0.0177^{* * *}$ & 0.0123 & 0.0134 & $0.0180^{* *}$ & $0.0186^{* *}$ \\
\hline & $(0.00598)$ & $(0.00597)$ & $(0.0125)$ & $(0.0125)$ & $(0.00818)$ & $(0.00817)$ \\
\hline \multirow{2}{*}{ YEAR2012 } & -0.000967 & -0.00101 & -0.00281 & -0.00259 & -0.00108 & -0.000994 \\
\hline & $(0.00328)$ & $(0.00324)$ & $(0.00300)$ & $(0.00299)$ & $(0.00287)$ & $(0.00286)$ \\
\hline \multirow[t]{2}{*}{ SECTOR6 } & $0.00521^{* *}$ & $0.00527^{* *}$ & & & 0.00551 & 0.00553 \\
\hline & $(0.00237)$ & $(0.00236)$ & & & $(0.00410)$ & $(0.00407)$ \\
\hline \multirow[t]{2}{*}{ PROSPEC } & & $0.0209^{* *}$ & & 0.0111 & & 0.0126 \\
\hline & & $(0.00825)$ & & $(0.0105)$ & & $(0.00900)$ \\
\hline \multirow[t]{2}{*}{ Constant } & $0.0587^{* * *}$ & $0.0650^{* * *}$ & $0.183^{* * *}$ & $0.201^{* * *}$ & $0.0616^{* * *}$ & $0.0743^{* * *}$ \\
\hline & $(0.00719)$ & $(0.00678)$ & $(0.0559)$ & $(0.0547)$ & $(0.0127)$ & $(0.0114)$ \\
\hline Observations & 1,890 & 1,890 & 1,890 & 1,890 & 1,890 & 1,890 \\
\hline $\mathrm{R}^{2}$ & 0.035 & 0.040 & 0.021 & 0.019 & & \\
\hline N. Firms & & & 333 & 333 & 333 & 333 \\
\hline
\end{tabular}

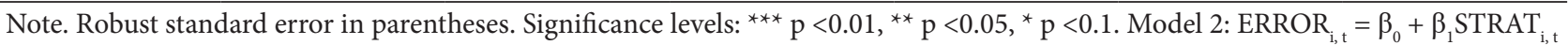
$+\beta_{3} \mathrm{X}_{\mathrm{i}, \mathrm{t}}+\gamma_{\mathrm{i}}+\varepsilon_{\mathrm{i}, \mathrm{t}}$. Model 3: ERROR $_{\mathrm{i}, \mathrm{t}}=\alpha_{0}+\alpha_{1}$ PROSPEC $_{\mathrm{i}, \mathrm{t}}+\alpha_{3} \mathrm{X}_{\mathrm{i}, \mathrm{t}}+\gamma_{\mathrm{i}}+\varepsilon_{\mathrm{i}, \mathrm{t}}$. Variables described previously. OLS, FE, and RE results for ordinary least squares, fixed effects by company, and random effects by company, respectively. Model 2 - Sig. Prob $>$ F 0.00 . VIF test: SIZE 1.03 / STRAT 1.02 / SECTOR6 1.01 / LEV 1.00 / YEAR2012 1.00 / Average VIF 1.01. White: p-value 0.01. Hausman: Prob> chi 0.01. Model 3 - Sig. Prob> F 0.00. VIF test: SIZE 1.01 / PROSPEC 1.00 / SECTOR6 1.01 / LEV 1.00 / YEAR2012 1.00 / Average VIF 1.01. White: p-value 0.01. Hausman: Prob $>\mathrm{chi}^{2}$ 0.01. The columns in bold are those that consider fixed effects.

with a prospector typology manage their earnings differently from other companies, does not present the same result as the average test. In this case, we cannot affirm that prospector companies engage in higher levels of earnings management when other aspects are similar to other types of companies, such as research, size, and indebtedness.

The coefficient associated with the PROSPEC variable presents a positive result of 0.0111 but does not present statistical significance for levels below 10\%. With these results, we cannot validate a higher level of earnings management for prospector companies, when the other characteristics of the company are kept constant. In other words, we cannot say that managers act consistently to manage earnings in prospector companies.

\subsection{Comparability with previous work}

Our results confirm the existence of earnings management in European companies. Thus, there is a relationship between the information produced by the accounting and the strategy of the company. This validates agency theory, which states that management may act to take advantage of opportunities and modify accounting information (Dal Magro et al., 2019). In the case of this research, a higher score in the strategy measure was accompanied by greater abnormalities in the earnings management measure.

The results suggest that $\mathrm{H} 1$ is confirmed. This result is in line with the findings of Bentley et al. (2013), who identified a relationship between strategy and irregularities in financial reporting in companies in the United States. We also confirmed the findings of Dal Magro et al. (2017), which identified that prospectors engage in more aggressive earnings management with the objective of increasing profits. Such relationships allow us to perceive possible consequences that may arise, such as a greater propensity for litigation, modified audit opinions, and impacts on market value, for example (Dechow et al., 2010). 
In the case of the second hypothesis, we cannot affirm that prospector companies act differently to modify earnings in European companies. As mentioned previously, Dal Magro et al. (2017) concluded that Brazilian prospector companies more clearly engage in earnings management with the objective of raising earnings levels.

Our paper is different from that of Dal Magro et al. (2017), which may explain the different results. When studying Brazilian companies, to identify discretionary accruals, they adopted the Kang and Sivaramakrishman (KS) model. Another difference is that in the present study we adopted the absolute value of the error found in the performance-modified Jones model. We also did not study whether there was an increase or decrease in accounting earnings. Our objective was to study whether earnings management exists or not. All these difference may explain the different findings we obtained.

We tested the same models for positive and negative discretion. Positive anomalies in accruals result in a higher level of earnings. Conversely, negative discretion results in a lower level of earnings (Martinez, 2008). The results are shown in Table 6. In the case of positive errors, the two strategy variables STRAT and PROSPEC do not present statistical significance at levels below 10\%. However, the difference of means test shows that prospector companies have a higher average positive error than the others at a significance level of $1 \%$. Positive earnings management on the part of prospector companies may be motivated by corporate or executive compensation issues, for example.

When we consider the negative errors, we find significance at the level of $1 \%$ for prospector companies. This difference is confirmed in the difference in means test. Prospectors present lower average values of negative errors than the other companies. Thus, we suggest that prospector companies engage in a higher level of earnings management compared to other types of companies in cases when earnings management is explained by the need to minimize earnings. In such cases, issues of tax aggressiveness, as dealt with by Higgins et al. (2015) and Marques et al. (2011), could be the main explanations.

Table 6

Results of regression models: earnings management. Positive and negative error values. Eurozone companies - 2011 to 2018.

\begin{tabular}{|c|c|c|c|c|}
\hline \multirow{2}{*}{ Variables } & (1) & $(2)$ & (3) & $(4)$ \\
\hline & ERROR (+) Model 2 & ERROR (+) Model 3 & ERROR (-) Model 2 & ERROR (-) Model 3 \\
\hline \multirow[t]{2}{*}{ STRAT } & 0.000591 & & -0.00158 & \\
\hline & $(0.000521)$ & & $(0.00175)$ & \\
\hline \multirow[t]{2}{*}{ SIZE } & -0.00468 & -0.00429 & $0.0310^{* * *}$ & $0.0299^{* * *}$ \\
\hline & $(0.00477)$ & $(0.00478)$ & $(0.0108)$ & $(0.0106)$ \\
\hline \multirow[t]{2}{*}{ LEV } & -0.0221 & -0.0215 & $-0.0418^{* *}$ & $-0.0455^{* *}$ \\
\hline & $(0.0174)$ & $(0.0172)$ & $(0.0204)$ & $(0.0213)$ \\
\hline \multirow[t]{2}{*}{ YEAR2012 } & -0.00144 & -0.00121 & 0.00467 & $-0.0300^{*}$ \\
\hline & $(0.00295)$ & $(0.00290)$ & $(0.00610)$ & $(0.0161)$ \\
\hline \multirow[t]{2}{*}{ PROSPEC } & & -0.00267 & & $0.0299^{* * *}$ \\
\hline & & $(0.00529)$ & & $(0.0106)$ \\
\hline \multirow[t]{2}{*}{ Constant } & 0.0901 & 0.0952 & $-0.363^{* * *}$ & $-0.372^{* * *}$ \\
\hline & $(0.0599)$ & $(0.0633)$ & $(0.128)$ & $(0.122)$ \\
\hline Observations & 1,157 & 1,157 & 733 & 733 \\
\hline $\mathrm{R}^{2}$ & 0.010 & 0.009 & 0.057 & 0.063 \\
\hline N. Firms & 273 & 273 & 226 & 226 \\
\hline
\end{tabular}

Note. Robust standard error in parentheses. Significance levels: ${ }^{* *} \mathrm{p}<0.01,{ }^{* *} \mathrm{p}<0.05,{ }^{*} \mathrm{p}<0.1$. ERRO2 $2_{\mathbf{i}, \mathbf{t}}=\beta_{0}+\beta_{1} \mathbf{S T R A T}_{\mathbf{i}, \mathbf{t}}+\beta_{3} \mathbf{X}_{\mathbf{i}, \mathbf{t}}+\gamma_{\mathbf{i}}+\varepsilon_{\mathbf{i}, \mathbf{t}}$; ERRO $_{\mathbf{i}, \mathbf{t}}=\beta_{0}+\beta_{1}$ STRAT $_{\mathbf{i}, \mathbf{t}}+\beta_{3} \mathbf{X}_{\mathbf{i}, \mathbf{t}}+\gamma_{\mathbf{i}}+\varepsilon_{\mathbf{i}, \mathbf{t}}$. Variables described previously. Model 2 ERROR (+): Sig. Prob > F 0.00. Test VIF: SIZE 1.05 / STRAT 1.03 / SECTOR6 1.04 / LEV 1.02 / YEAR2012 1.00 / Mean VIF 1.03. White: p-value 0.00. Hausman: Prob > chi ${ }^{2} 0.03$. Model 3 ERROR (+): Sig. Prob > F 0.00. Test VIF: SIZE 1.04 / PROSPEC 1.01 / SECTOR6 1.03 / LEV 1.02 / YEAR2012 1.00 / Mean VIF 1.02. White: p-value 0.01. Hausman: Prob > chi ${ }^{2}$ 0.02. Model 2 ERROR (-) Sig. Prob > F 0.03. Test VIF: SIZE 1.04 / STRAT 1.09 / SECTOR6 1.06 / LEV 1.01 / YEAR2012 1.00 / Mean VIF 1.04. White: p-value 0.00. Hausman: Prob > chi² 0.00. Model 3 ERROR (-) Sig. Prob > F 0.00. Test VIF: SIZE 1.01 / PROSPEC 1.02 / SECTOR6 1.02 / LEV 1.01 / YEAR2012 1.00 / Mean VIF 1.01. White: p-value 0.06. Hausman: Prob $>$ chi $^{2} 0.00$ 


\section{Conclusion}

In this article we used agency theory (Jensen \& Meckling, 1976) as a starting point to investigate the relationship between business strategy and earnings management. We adopted the strategy typology of Miles et al. (1978) to categorize the strategy adopted by companies operating in the Eurozone. Based on the theory of Miles et al. (1978), the strategy measures were developed using the contributions by Ittner and Larcker (2012), Bentley et al. (2013), and Higgins et al. (2015). Regarding the earnings management measure, we used the research by Dechow et al. (2010), applying the performancemodified Jones model, as adopted by Marques et al. (2011) in the case of Portuguese companies and by Martinez and Moraes (2017) for Brazilian companies.

This paper uses data on Eurozone companies that were collected from the Amadeus database. The main objective was to investigate the relationship between strategic behavior and earnings management. We structured regression models that considered the particularities of the companies. The tests converged to suggest a better specification of the regression model with fixed effects. The STRAT strategy measure proved to be statistically significant at $10 \%$ in relation to the abnormal accruals measure, a proxy for earnings management. This paper is important for users since it corroborates the idea that the corporate strategy influences earnings management, a phenomenon that has important consequences.

We were not successful in validating the hypothesis that earnings management in prospector companies is greater than in other companies. The difference of means test suggests that this type of company presents more abnormal accruals in relation to other companies. But the regression model did not corroborate this result. However, additionally, we conducted tests in which the discretionary accruals were separated into positive and negative values. In this case, the results suggest a positive relationship between prospector companies and negative abnormality of accruals.

This study contributes to the literature because it is the first to address how strategic behavior influences earnings management in a sample of listed companies from five European countries. The study shows that there is a relationship between earnings management and strategy, which corroborates the assumptions of agency theory. We contribute to the theory of strategic behavior since we reveal that the strategy measure has a relationship with the entity's accounting choices.

This study also has limitations. The first limitation is the scarcity of data necessary for the calculation of strategy measures, which restricted the number of countries included in the final sample. We opted to fully follow the previous literature regarding the development of strategy measures, even with some loss of information, which restricted the research to five countries in the Eurozone. This option provides better comparability of the results with previous research applied in other markets. At this point, we offer the suggestion of expanding future works to searches in other databases.

Additionally, as further research, it would be interesting to adopt other measures for earnings management, such as the Kang and Sivaramakrishman model, for example. This suggestion is important considering the limitations of the models for estimating the abnormality of accruals.

This research showed that corporate strategy influences earnings management. Although it was not possible to prove the second hypothesis, the data indicate that earnings management seems to be more likely in prospector companies. Thus, this study reinforces the previous literature since it shows, for a sample of European companies, that strategic behaviors influence accounting choices. Researchers, managers, and regulators can benefit from the findings of this paper. Studying the determinants of the quality of accounting information is important, as highlighted by Dechow et al. (2010).

As for future research, it would be interesting to carry out investigations in other markets and in other countries, in order to better understand how the strategic behavior of companies affects earnings management. In countries with a small number of listed companies, we suggest further research using qualitative methodologies.

\section{References}

BALL, R. \& SHIVAKUMAR, L. Earnings quality in UK private firms: Comparative loss recognition timeliness. Journal of Accounting and Economics, v. 39, n. 1, p. 83-128, 2005. https://doi.org/10.1016/j.jacceco.2004.04.001 
BENTLEY, K. A., OMER, T. C., \& SHARP, N. Y. (2013). Business strategy, financial reporting irregularities, and audit effort. Contemporary Accounting Research, 30(2), 780-817. https://doi.org/10.1111/j.1911-3846.2012.01174.x

CAMERAN, M., CAMPA, D., \& PETTINICCHIO, A. (2014). IFRS adoption among private companies: Impact on earnings quality. Journal of Accounting, Auditing and Finance, 29(3), 278-305.https://doi. org/10.1177/0148558X14534260

DAL MAGRO, C. B., JESUS SILVA, T. B. DE, \& KLANN, R. C. (2017). Comportamento estratégico organizacional e a prática de gerenciamento de resultados nas empresas brasileiras. Revista Ibero-Americana de Estratégia, 16(01), 119-137. https://doi.org/10.5585/ riae.v16i1.2389

DAL MAGRO, C. B., LAVARDA, C. E. F., \& KLANN, R. C. (2019). Study Approaches on Result Management: New Perspectives From Bibliometric Analysis. Revista Mineira de Contabilidade, 20(1), 34-49. https://doi. org/10.21714/2446-9114RMC2019v20n1t03

DECHOW, P., GE, W., \& SCHRAND, C. (2010). Understanding earnings quality: A review of the proxies, their determinants and their consequences. Journal of Accounting and Economics, 50(2-3), 344-401. https:// doi.org/10.1016/j.jacceco.2010.09.001

DEFOND, M. \& PARK, C., W. (2001). The Reversal of Abnormal Accruals and the Market Valuation of Earnings Surprises Authors (s): Mark L . DeFond and Chul W . Park Source: The Accounting Review, Vol . 76, No . 3 (Jul ., 2001), pp . 375-404 Published by: American Accounting Associati. The Accounting Review, 76(3), 375-404.

FERREIRA, F. R., MARTINEZ, A. L., COSTA, F. M. DA, \& PASSAMANI, R. R. (2012). Book-tax differences e gerenciamento de resultados no mercado de açóes do Brasil. Revista de Administração de Empresas, 52(5), 488-501. https://doi.org/10.1590/S0034-75902012000500002

HEALY, P. M., \& WAHLEN, J. M. (1999). A review of the earnings management literature and its implications for standard setting. Accounting Horizons, 13(4), 365-383. https://doi.org/10.2308/acch.1999.13.4.365
HIGGINS, D., OMER, T. C., \& PHILliPS, J. D. (2015). The influence of a firm's business strategy on its tax aggressiveness. Contemporary Accounting Research, 32(2), 674-702. https://doi.org/10.1111/1911-3846.12087

HOGAN, R., \& EVANS, J. D., Does the strategic alignment of value drivers impact earnings persistence? Sustainability Accounting, Management and Policy Journal, v. 6, n. 3, p. 374-396, 2015. http://dx.doi.org/10.1108/ SAMPJ-11-2014-0073

HOUQE, M. N., KERR, R., \& MONEM, R., Business Strategy and CRM: Working Papers. Wellington: 2013. Retrieved from: https://www.wgtn.ac.nz/cagtr/workingpapers/wp-92.pdf.

ITTNER, C. D., \& LARCKER, D. F. (2012). The choice measures bonus of in performance annual contracts. The Accounting Review, 72(2), 231-255. https://doi. org/10.2307/248554

JENSEN, M. C., \& MECKLING, W. H. (1976). Theory of the firm: Managerial behavior, agency costs and ownership structure. Journal of Financial Economics, 3(4), 305-360. https://doi.org/10.1016/0304-405X(76)90026-X

KOTHARI, S. P., LEONE, A. J., \& WASLEY, C. E. (2005). Performance matched discretionary accrual measures. Journal of Accounting and Economics, 39(1), 163-197. https://doi.org/10.1016/j.jacceco.2004.11.002

MARCH, J. G. 1991. Exploration and Exploitation in Organizational Learning. Organization Science, 2 (1): 71-87. https://doi.org/10.1287/orsc.2.1.71

MARQUES, M., RODRIGUES, L. L., \& CRAIG, R. (2011). Earnings management induced by tax planning: The case of Portuguese private firms. Journal of International Accounting, Auditing and Taxation, 20(2), 83-96. https:// doi.org/10.1016/j.intaccaudtax.2011.06.003

MARTINEZ, A., L. (2008). Detectando Earnings management no Brasil: estimando os accruals discricionários. Revista Contabilidade \& Finanças, 19(46), 7-17. https:// doi.org/10.1590/S1519-70772008000100002

MARTINEZ, A. L., \& MORAES, A. de J. (2017). Relationship between auditors' fees and earnings management. Revista de Administração de Empresas, 57, 148-157. 
Recuperado de http://www.scielo.br/scielo.php?script=sci_ arttext\&pid=S0034-75902017000200148\&lang=pt

MARTINEZ, A., L. \& MORAES, A. de J. (2017). Relationship between auditors' fees and earnings management. Revista de Administração de Empresas, 57, 148-157. Retrieved from http://www.scielo.br/scielo.php?script=sci_ arttext\&pid=S0034-75902017000200148\&lang=pt

MARTINEZ, A., L. \& REIS, G. M. R. (2010). Rodízio das firmas de auditoria e o gerenciamento de resultados no Brasil. RCO - Revista de Contabilidade e Organizaçôes, 4(10), 48-64. https://doi.org/101590/S0034-759

MENDES, C., A. \& RODRIGUES, L., L. Determinantes da Manipulação Contabilística. Revista de Estudos Politécnicos, v. IV, n. 7, p. 189-210, 2007.

MILES, R. E., SNOW, C. C., MEYER, A. D., \& COLEMAN Jr, H. (1978). Organizational strategy, structure, and process. Academy of Management Review, 3(3), 546-562. https://doi.org/10.5465/AMR.1978.4305755

MILES, R. E., SNOW, C. C., MEYER, A. D., \& COLEMAN Jr, H. (2003). Organizational strategy, structure, and process. In Stanford University Press (Vol. 3). Stanford University.

PORTER, M. E. (1980). Competitive Strategy. New York: Free Press.
ORESTES DA SILVA, J., \& BEZERRA, F. A. (2010). Análise do Gerenciamento de Resultados e o Rodízio de Firmas de Auditoria nas Empresas de Capital Aberto. Revista Brasileira de Gestao de Negocios, 12(36), 304-321.

SANTOS, P. S. DOS, MACHADO, D. G., \& SCARPIN, J. E. (2012). Gerenciamento de Resultados no Setor Público : Análise por meio das Contas Orçamentárias Outras Receitas e Despesas Correntes dos Municípios de Santa Catarina. Revista Contabilidade Vista \& Revista, 23(4), 15-43.

SCHIPPER, K. (1989). Commentary on earnings management. Accounting Horizons, 3(4), 91-102.

SEJATI, Y. A. (2009). Political connnection and earnings quality: Evidence from Malaysia.

TREACY, M., and F. WIERSEMA. 1995. The discipline of market leaders. Reading, MA: AddisonWesley.

VERBEEK, M. (2017). A Guide to modern Econometrics. Rotterdam: Wiley.

WU, P., GAO, L., \& GU, T. Business strategy, market competition and earnings management: Evidence from China. Chinese Management Studies, v. 9, n. 3, p. 401-424, 2015. Available at: https://doi.org/10.1108/ CMS-12-2014-0225

\section{Financial support:}

This research was supported by NIPE through National Funds provided by FCT - Portuguese Foundation for Science and Technology within the project UIDB/03182/2020.

\section{Conflicts of interest:}

None.

\section{Copyrights:}

RBGN owns the copyrights of this published content.

\section{Plagiarism analysis:}

RBGN performs plagiarism analysis on all its articles at the time of submission and after approval of the manuscript using the iThenticate tool.

\section{Authors:}

1. Luciano Pinheiro de Sá, PhD in Business Administration, Federal University of Juiz de Fora (UFJF), Brazil. luciano.pinheiro@uff.br 
2. Lúcia Lima Rodrigues, PhD in Business Administration, University of Minho, Braga, Portugal. lrodrigues@eeg.uminho.pt 3. Josir Simeone Gomes, Post Doctorate, Unigranrio, Rio de Janeiro, Brazil.

josirsgomes@gmail.com

\section{Authors' Contributions:}

$\mathbf{1}^{\text {st }}$ author: Definition of research problem; Development of hypotheses or research questions (empirical studies);

Development of theoretical propositions (theoretical work); Definition of methodological procedures; Data Collection;

Literature review; Statistical analysis; Analysis and interpretation of data; Critical revision of the manuscript; Manuscript writing.

$2^{\text {nd }}$ author: Definition of research problem; Definition of methodological procedures; Literature review; Statistical analysis; Analysis and interpretation of data; Critical revision of the manuscript; Manuscript writing.

$3^{\text {rd }}$ author: Definition of research problem; Development of hypotheses or research questions (empirical studies); Definition of methodological procedures; Literature review; Analysis and interpretation of data; Critical revision of the manuscript. 